\title{
Antifungal and plant growth promoting activity with Bacillus amyloliquefaciens in Aeonium subs.
}

\author{
Domenico Prisa* \\ CREA Research Centre for Vegetable and Ornamental Crops, Council for Agricultural Research and Economics, Via dei \\ Fiori 8, 51012 Pescia, PT, Italy.
}

Magna Scientia Advanced Biology and Pharmacy, 2021, 01(02), 042-050

Publication history: Received on 10 January 2021; revised on 15 February 2021; accepted on 17 February 2021

Article DOI: https://doi.org/10.30574/msabp.2021.1.2.0008

\begin{abstract}
In this work, the biostimulant and biocontrol capacity of Bacillus amyloliquefaciens in succulent plants such as Aeonium was evaluated. The specific objectives were in particular: (i) Evaluate whether the use of this bacterium can increase the growth rate of Aeonium plants that typically have a slow growth cycle; (ii) evaluate if the use of B. amyloliquefaciens can lead to increased plant resistance to Fusarium oxysporum; (iii) considered if utilization of B. amyloliquefaciens allows for increased plant resistance to water and nutrient stress. The experimentation showed a significant improvement of the agronomic parameters analyzed on all Aeonium plants treated with Bacillus amyloliquefaciens. In general there was a significant increase in plant height, number of leaves, vegetative and root weight, number of new shoots. In addition, Aeonium goochiae and sunburst show a better protection against the fungus Fusarium oxysporum. The trial also highlighted the ability of B. amyloliquefaciens to guarantee a productive and qualitative production of the plants even under conditions of reduced water and nutritional resources. Plants, thanks to the interaction with soil microorganisms, can reach higher nutrient and water resources, resulting in greater resistance to abiotic stresses and better quality in the cultivation cycle.
\end{abstract}

Keywords: Crassulaceae; Microorganisms; Sustainable agriculture; Plant quality; Rhizosphere

\section{Introduction}

Crassulaceae are dicolythedonous plants, with succulent leaves, arranged in a rosette; they can take on the size of grasses or shrubs; only a few species are annuals or biennials. Leaves are often covered with bloom, with great variety of shapes and colors. They have a certain basic number of sepals and petals, stamens and carpels; the flowers are small, star-shaped or tubular, mostly bisexual, white, red or yellow, forming corymbs or panicles; many species are self-fertile but need pollination [1]. The fruit is a follicle that opens at maturity whose seeds, very small, are dispersed by the wind. Some species bloom in winter, others in spring or late summer. European species are mostly hardy. Aeonium is characterized by some forty species of perennial grasses or shrubs, with or without branches, with or without stems, bearing a rosette at the top of the stems that dies after flowering (monocarpic genus) [2]. During the dry period, the outer leaves die. Flower color ranges from white, to golden yellow, to pink. It identifies the group without stems including the species: canariense, cuneatum, glandolosum, palmense, subplanum, tabuliforme, virgineum. The branched, dwarf group consisting of: haworthii, lindleyi, saundersii, sedifolium, smithii, spathulatum, viscatum [3]. Then we have a group including large shrubs over a meter tall: arboreum, balsamiferum, rubrolineatum, undulatum, urbicum. These are plants from the Canary Islands, the southern Mediterranean, East Africa, Arabia [4]. They grow in general from sea level up to 2000 meters. In the wild the growing season is between October and March, coinciding with the rainy season in the Canary Islands, however the plants can be encouraged to vegetate in the summer and become more

\footnotetext{
${ }^{*}$ Corresponding author: Domenico Prisa

CREA Research Centre for Vegetable and Ornamental Crops, Council for Agricultural Research and Economics, Via dei Fiori 8, 51012 Pescia, PT, Italy.
} 
robust if planted in the ground during the good season and potted up again in the fall. In summer, however, they like an outdoor exposure. They are subject to rot; propagation is by apical stem cuttings or leaf cuttings resting on the soil; in late summer you can also practice the sowing [5,6].

Bacillus strains manifest their biological control capabilities by producing a broad spectrum of antibiotics, synthesizing extracellular enzymes and competing for nutrients, also resulting in processes of inducing systemic resistance in plants against pathogens $[7,8]$. Several studies have shown that VOCs produced by Bacillus spp. are able to inhibit spore germination of several fungal plant pathogens $[9,10]$. In addition to anti-fungal activity, VOCs can improve growth and induce resistance against plant pathogens [11,12,13]. Several studies have shown that secretion of secondary metabolites is the most important mechanism to suppress pathogens; lipopeptides are the most important secreted metabolites and have been reported to effectively antagonize plant pathogens [14]. Iturin A, a lipopeptide that is produced by Bacillus amyloliquefaciens, has shown excellent antifungal activity against several plant pathogens [15,16]. It may also play a positive role in biofilm formation $[17,18]$. The biocontrol activity and mechanism of $B$. amyloliquefaciens have been well studied in recent years. B. amyloliquefaciens strains also produce plant growthpromoting hormones including indole-3-acetic acid (IAA) and gibberellin A3 (GA3) and several nutrient-related enzymes [19]. In addition, phosphorus solubilization and nitrogen fixation are other characteristics that promote plant growth of B. amyloliquefaciens strains [20].

In this experiment, the main objective was to:

- Evaluate whether the use of this bacterium can increase the growth rate of Aeonium plants that typically have a slow growth cycle;

- $\quad$ Evaluate if the use of B. amyloliquefaciens can lead to increased plant resistance to Fusarium oxysporum;

- Considered if utilization of B. amyloliquefaciens allows for increased plant resistance to water and nutrient stress.

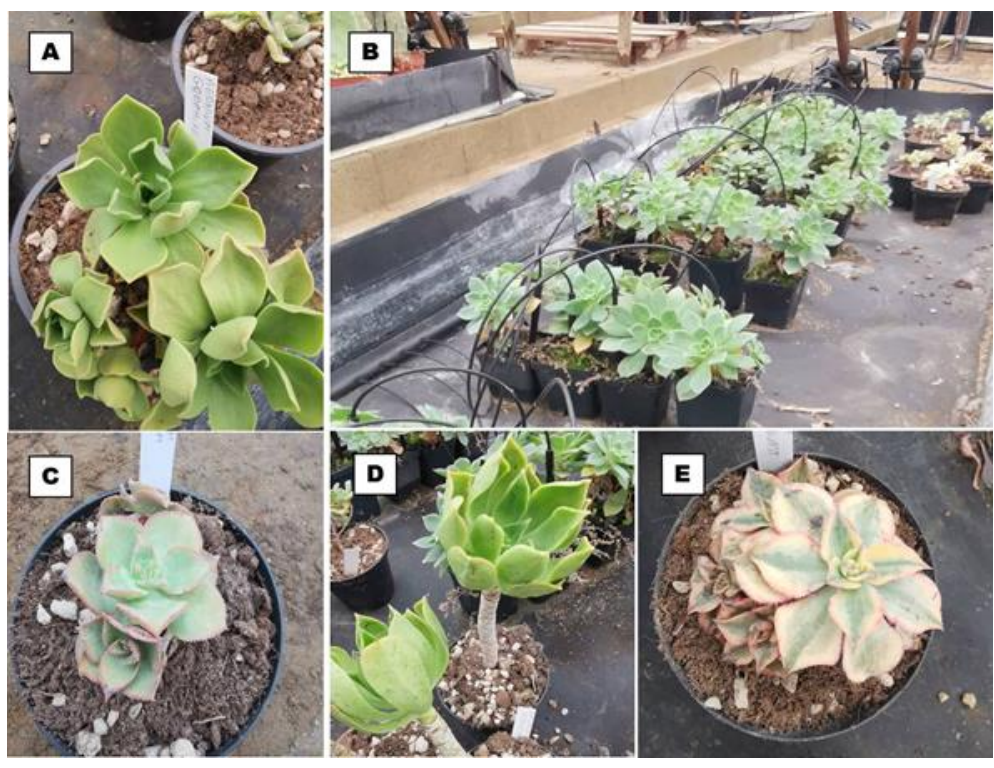

Figure 1 - Particular of Aeonium subs. in greenhouse cultivation: Aeonium goochiae (A); Aeonium haworthii (B); Aeonium decorum (C); Aeonium arboreum (D); Aeonium cv sunburts

\section{Material and methods}

The experiments, started in January 2020, were conducted in the greenhouses of CREA-OF in Pescia (Pt), Tuscany, Italy $\left(43^{\circ} 54^{\prime} \mathrm{N} 10^{\circ} 41^{\prime} \mathrm{E}\right)$ on Aeonium arboreum, Aeonium haworthii, Aeonium decorum, Aeonium goochiae, Aeonium cv. sunburts (Figure 1A,1B). The plants were placed in $\emptyset 10 \mathrm{~cm}$ pots; 30 plants per thesis, divided into 3 replicas of 10 plants each. All plants were fertilized with a controlled release fertilizer $\left(1 \mathrm{~kg} \mathrm{~m}^{-3}\right.$ Osmocote Pro®, 9-12 months with $190 \mathrm{~g} / \mathrm{kg}$ $\mathrm{N}, 39 \mathrm{~g} / \mathrm{kg} \mathrm{P}, 83 \mathrm{~g} / \mathrm{kg} \mathrm{K}$ ) mixed with the growing medium before transplanting. The experimental groups were:

- Group without B. amyloliquefaciens (CTRL100) (peat 60\% + pumice 40\%), irrigated with water (100\%) and substrate previously fertilized (100\%); 
- Group without B. amyloliquefaciens (CTRL50) (peat 60\% + pumice 40\%) irrigated with water (50\%) and substrate previously fertilized (50\%);

- Group with B. amyloliquefaciens (BAM100) (peat 60\% + pumice 40\%) irrigated with water (100\%) and substrate previously fertilized (100\%); B. amyloliquefaciens has been isolated by TNC Mycorr MAX (1.2 x109 $\mathrm{cfu} / \mathrm{Kg}$ )

- Group with B. amyloliquefaciens (BAM50) (peat 60\% + pumice $40 \%$ ) irrigated with water (50\%) and substrate previously fertilized (50\%);

The plants were watered 4 times a week in the CTRL100 and BAM100 and grown for 12 months. The plants were irrigated with drip irrigation. The irrigation was activated by a timer whose program was adjusted weekly according to climatic conditions and the fraction of leaching. On January 7, 2021, plant height, leaves number, vegetative weight, roots weight, shoots number. In addition, the number of plants that died to Fusarium oxysporum were evaluated.

\subsection{Statistics}

The experiment was carried out in a randomized complete block design. Collected data were analysed by one-way ANOVA, using GLM univariate procedure, to assess significant $(P \leq 0.05,0.01$ and 0.001$)$ differences among treatments. Mean values were then separated by LSD multiple-range test $(P=0.05)$. Statistics and graphics were supported by the programs Costat (version 6.451) and Excel (Office 2010).

\section{Results and discussion}

The experimentation showed a significant improvement of the agronomic parameters analyzed on all Aeonium plants treated with Bacillus amyloliquefaciens. In general there was a significant increase in plant height, number of leaves, vegetative and root weight, number of new shoots. In addition, Aeonium goochiae and sunburst show a better protection against the fungus Fusarium oxysporum. The trial also highlighted the ability of B. amyloliquefaciens to guarantee a productive and qualitative production of the plants even under conditions of reduced water and nutritional resources. Plants treated with B. amyloliquefaciens and 50\% water and fertilizer showed the same agronomic results as the control with $100 \%$ water and fertilizer.

In (Table 1), in Aeonium haworthii there was a significant increase in plant height in (BAM100) with $13.69 \mathrm{~cm}$ compared to $12.64 \mathrm{~cm}$ in (CTRL100), $12.60 \mathrm{~cm}$ in (BAM50) and $11.20 \mathrm{~cm}$ in (CTRL50) (Figure 2). In addition, there was a significant increase in leaf number 6.70 in the (BAM100) thesis, compared to 5.71 in the control at optimal fertilization and irrigation and 4.80 in (BAM50) and (CTRL50). Regarding vegetative weight, the (BAM100) thesis was the best with $29.82 \mathrm{~g}$, followed by (CTRL100) with 27.51g, (BAM50) $27.50 \mathrm{~g}$ and (CTRL50) with $23.99 \mathrm{~g}$. The same trend for root weight where (BAM100) showed a weight of $17.86 \mathrm{~g}$, (CTRL100) $15.73 \mathrm{~g}$, (BAM50) $15.64 \mathrm{~g}$ and (CTRL50) $14.49 \mathrm{~g}$ (Figure 3). In terms of the number of new shoots, (BAM100) was also the best thesis with 5.40, followed by (CTRL100) and (BAM50) with 3.60 and 3.30, respectively, and finally (CTRL50) with 2.20. There were no significant differences in mortality caused by Fusarium oxysporum in the different experimental theses.

In (Table 2), in Aeonium goochiae there was a significant increase in plant height in (BAM100) with $9.93 \mathrm{~cm}$ compared to $8.84 \mathrm{~cm}$ in (BAM50), $8.51 \mathrm{~cm}$ in (CTRL100) and $7.60 \mathrm{~cm}$ in (CTRL50). In the treated thesis (BAM100) there was also a significant increase in the number of leaves 8.30, compared to 7.20 (BAM50), 6.40 (CTRL100) and 5.30 (CTRL50). In terms of vegetative weight, the thesis (BAM100) was the best with $42.42 \mathrm{~g}$, followed by (BAM50) with $40.43 \mathrm{~g}$, (CTRL100) $39.45 \mathrm{~g}$ and (CTRL50) with $35.95 \mathrm{~g}$ (Figure 4A). The same trend for root weight where (BAM100) showed a weight of $30.85 \mathrm{~g}$, (CTRL100) 27.69 g, (BAM50) $27.42 \mathrm{~g}$ and (CTRL50) $24.89 \mathrm{~g}$. For number of new shoots, (BAM100) was also the best thesis with 3.40, followed by (CTRL100) with 2.20 and (BAM50) and (CTRL50) with 1.80. Regarding the biocontrol of F.oxysporum, theses with B. amyloliquefaciens were the one with significantly lower mortality.

In (Table 3), in Aeonium decorum there was a significant increment in plant height in (BAM100) with $6.27 \mathrm{~cm}$ compared to $5.25 \mathrm{~cm}$ in (BAM50), $4.99 \mathrm{~cm}$ in (CTRL100) and $3.95 \mathrm{~cm}$ in (CTRL50). In the treated thesis (BAM100) there was also a significant increase in leaf number 5.80, compared to 4.70 (BAM50), 4.60 (CTRL100), and 4.20 (CTRL50).In relation to vegetative weight, the (BAM100) thesis was the best with $27.61 \mathrm{~g}$, compared to (CTRL100) with $25.98 \mathrm{~g}$, (BAM50) $25.62 \mathrm{~g}$ and (CTRL50) with $24.23 \mathrm{~g}$ (Figure 4B). The same tendency for root weight where (BAM100) showed a weight of $19.24 \mathrm{~g}$, (BAM50) $18.43 \mathrm{~g}$, (CTRL100) $17.57 \mathrm{~g}$ and (CTRL50) $15.18 \mathrm{~g}$. As for number of new shoots, (BAM100) was also the best thesis with 3.60, followed by (CTRL100) and (BAM50) with 2.20 and (CTRL50) with 1.10. Concerning the biocontrol of F.oxysporum, there were no significant differences among the experimental theses. 
In (Table 4), in Aeonium arboreum there was a significant increase in plant height in (BAM100) with $18.05 \mathrm{~cm}$ compared to $14.97 \mathrm{~cm}$ in (BAM50), $14.91 \mathrm{~cm}$ in (CTRL100) and $13.41 \mathrm{~cm}$ in (CTRL50) (Figure 5). In the treated thesis (BAM100) there was also a significant increase in leaf number 6.40, compared to 5.00 in (BAM50) and (CTRL100) and 3.80 (CTRL50).Regarding vegetative weight, the (BAM100) thesis was the best with $43.48 \mathrm{~g}$, succeeded by (CTRL100) with $42.66 \mathrm{~g}$ and (BAM50) $42.25 \mathrm{~g}$ and finally (CTRL50) with $38.22 \mathrm{~g}$. Same performance for root weight where (BAM100) showed a weight of $30.58 \mathrm{~g}$, (CTRL100) $26.68 \mathrm{~g}$, (CTRL50) $22.77 \mathrm{~g}$ and (BAM50) 21.79 g. For number of new shoots, (BAM100) was also the best thesis with 2.80, followed by (CTRL100) with 1.61 and (BAM50) with 1.42 and (CTRL50) with 1.00. Concerning the biocontrol of F.oxysporum also on this succulent species, there were no significant differences among the various experimental theses.

In (Table 5), in Aeonium cv sunburst there was a significant increase in plant height in (BAM100) with 8.61 cm compared to $7.56 \mathrm{~cm}$ in (CTRL100), $7.18 \mathrm{~cm}$ in (BAM50) and $6.43 \mathrm{~cm}$ in (CTRL50). In the treated thesis (BAM100) there was also a significant increase in leaf number 6.40, compared to 5.20 in (BAM50) and (CTRL100) and 4.10 (CTRL50).In terms of vegetative weight, the (BAM100) thesis was the best with $26.84 \mathrm{~g}$, followed by (CTRL100) with $24.68 \mathrm{~g}$ and (BAM50) $24.61 \mathrm{~g}$ and finally (CTRL50) with $22.97 \mathrm{~g}$. Same trend for root weight where (BAM100) showed a weight of $15.94 \mathrm{~g}$, (CTRL100) 13.35 g, (BAM50) $13.29 \mathrm{~g}$ and (CTRL50) $12.91 \mathrm{~g}$. For the number of new shoots, (BAM100) was also the best thesis with 5.60, followed by (CTRL100) with 4.20 and (CTRL50) with 3.40 and (BAM50) with 3.20 (Figure 6). Regarding the biocontrol of F.oxysporum, the treated experimental theses (BAM100) and (BAM50) were the best.

Table 1- Evaluation of B. amyloliquefaciens on the agronomic characters of Aeonium haworthii

\begin{tabular}{|c|c|c|c|c|c|c|}
\hline Groups & $\begin{array}{c}\text { Plant } \\
\text { height } \\
\text { (cm) }\end{array}$ & $\begin{array}{c}\text { Leaves } \\
\text { number } \\
\mathbf{( n}^{\circ} \mathbf{)}\end{array}$ & $\begin{array}{c}\text { Vegetative } \\
\text { weight } \\
\mathbf{( g )}\end{array}$ & $\begin{array}{c}\text { Roots } \\
\text { weight } \\
\mathbf{( g )}\end{array}$ & $\begin{array}{c}\text { Shoots } \\
\text { number } \\
\text { (n) }\end{array}$ & $\begin{array}{c}\text { F.oxysporum } \\
\text { plants } \\
\text { affected (n }\end{array}$ \\
\hline CTRL100 & $12,64 \mathrm{~b}$ & $5,71 \mathrm{~b}$ & $27,51 \mathrm{~b}$ & $15,73 \mathrm{~b}$ & $3,60 \mathrm{~b}$ & $0,61 \mathrm{a}$ \\
\hline CTRL50 & $11,20 \mathrm{c}$ & $4,80 \mathrm{c}$ & $23,99 \mathrm{c}$ & $14,49 \mathrm{c}$ & $2,20 \mathrm{c}$ & $0,44 \mathrm{ab}$ \\
BAM100 & $13,69 \mathrm{a}$ & $6,70 \mathrm{a}$ & $29,82 \mathrm{a}$ & $17,86 \mathrm{a}$ & $5,40 \mathrm{a}$ & $0,00 \mathrm{~b}$ \\
BAM50 & $12,60 \mathrm{~b}$ & $4,80 \mathrm{c}$ & $27,50 \mathrm{~b}$ & $15,64 \mathrm{~b}$ & $3,30 \mathrm{~b}$ & $0,00 \mathrm{~b}$ \\
\hline ANOVA & $* * *$ & $* * *$ & $* * *$ & $* * *$ & $* * *$ & $\mathbf{n s}$ \\
\hline
\end{tabular}

One-way ANOVA; n.s. - non significant; ${ }^{* * *, * * *}$ - significant at $\mathrm{P} \leq 0.05,0.01$ and 0.001 , respectively; different letters for the same element indicate significant differences according to Tukey's (HSD) multiple-range test $(\mathrm{P}=0.05)$.Legend: (CTRL100): control with $100 \%$ water and fertilization; (CTRL50): control with 50\% water and fertilization; (BAM100): B. amyloliquefaciens with 100\% water and fertilization; (BAM50): B. amyloliquefaciens with $50 \%$ water and fertilization.

Table 2 - Evaluation of B. amyloliquefaciens on the agronomic characters of Aeonium goochiae

\begin{tabular}{|c|c|c|c|c|c|c|}
\hline Groups & $\begin{array}{c}\text { Plant } \\
\text { height } \\
\text { (cm) }\end{array}$ & $\begin{array}{c}\text { Leaves } \\
\text { number } \\
\left(\mathbf{n}^{\circ}\right)\end{array}$ & $\begin{array}{c}\text { Vegetative } \\
\text { weight } \\
\text { (g) }\end{array}$ & $\begin{array}{c}\text { Roots } \\
\text { weight } \\
\text { (g) }\end{array}$ & $\begin{array}{c}\text { Shoots } \\
\text { number } \\
\left(n^{\circ}\right)\end{array}$ & $\begin{array}{c}\text { F.oxysporum } \\
\text { plants } \\
\text { affected }\left(\mathrm{n}^{\circ}\right)\end{array}$ \\
\hline CTRL100 & $8,51 \mathrm{~b}$ & $6,40 \mathrm{c}$ & $39,45 \mathrm{~b}$ & $27,69 \mathrm{~b}$ & $2,20 \mathrm{~b}$ & $1,81 \mathrm{a}$ \\
\hline CTRL50 & $7,60 \mathrm{c}$ & $5,30 \mathrm{~d}$ & $35,95 \mathrm{c}$ & $24,89 \mathrm{c}$ & $1,80 \mathrm{~b}$ & $1,64 \mathrm{a}$ \\
\hline BAM100 & $9,93 \mathrm{a}$ & $8,30 \mathrm{a}$ & $42,42 \mathrm{a}$ & $30,85 \mathrm{a}$ & $3,40 \mathrm{a}$ & $0,45 \mathrm{~b}$ \\
\hline BAM50 & $8,84 \mathrm{~b}$ & $7,20 \mathrm{~b}$ & $40,43 \mathrm{~b}$ & $27,42 \mathrm{~b}$ & $1,80 \mathrm{~b}$ & $0,62 \mathrm{~b}$ \\
\hline ANOVA & $* * *$ & $* * *$ & $* * *$ & $* * *$ & $* * *$ & $* *$ \\
\hline
\end{tabular}

One-way ANOVA; n.s. - non significant; ${ }^{* * *}, * * *$ - significant at $\mathrm{P} \leq 0.05,0.01$ and 0.001 , respectively; different letters for the same element indicate significant differences according to Tukey's (HSD) multiple-range test ( $\mathrm{P}=0.05)$.Legend: (CTRL100): control with $100 \%$ water and fertilization; (CTRL50): control with 50\% water and fertilization; (BAM100): B. amyloliquefaciens with 100\% water and fertilization; (BAM50): B. amyloliquefaciens with $50 \%$ water and fertilization 
Table 3 - Evaluation of B. amyloliquefaciens on the agronomic characters of Aeonium decorum

\begin{tabular}{|c|c|c|c|c|c|c|}
\hline Groups & $\begin{array}{c}\text { Plant } \\
\text { height } \\
(\mathrm{cm})\end{array}$ & $\begin{array}{c}\text { Leaves } \\
\text { number } \\
\left(n^{\circ}\right)\end{array}$ & $\begin{array}{c}\text { Vegetative } \\
\text { weight } \\
\text { (g) }\end{array}$ & $\begin{array}{c}\text { Roots } \\
\text { weight } \\
\text { (g) }\end{array}$ & $\begin{array}{c}\text { Shoots } \\
\text { number } \\
\left(n^{\circ}\right)\end{array}$ & $\begin{array}{c}\text { F.oxysporum } \\
\text { plants } \\
\text { affected }\left(n^{\circ}\right)\end{array}$ \\
\hline CTRL100 & $4,99 \mathrm{c}$ & $4,60 \mathrm{~b}$ & $25,98 \mathrm{~b}$ & $17,57 \mathrm{~b}$ & $2,20 \mathrm{~b}$ & $0,60 \mathrm{a}$ \\
\hline CTRL50 & $3,95 \mathrm{~d}$ & $4,20 \mathrm{~b}$ & $24,23 \mathrm{c}$ & $15,18 \mathrm{c}$ & $1,10 \mathrm{c}$ & $0,41 \mathrm{ab}$ \\
\hline BAM100 & $6,27 \mathrm{a}$ & $5,80 \mathrm{a}$ & $27,61 \mathrm{a}$ & $19,24 \mathrm{a}$ & $3,60 \mathrm{a}$ & $0,00 \mathrm{~b}$ \\
\hline BAM50 & $5,25 \mathrm{~b}$ & $4,70 \mathrm{~b}$ & $25,62 \mathrm{~b}$ & $18,43 \mathrm{ab}$ & $2,20 \mathrm{~b}$ & $0,21 a b$ \\
\hline ANOVA & $* * *$ & $* * *$ & $* * *$ & $* * *$ & $* * *$ & ns \\
\hline
\end{tabular}

One-way ANOVA; n.s. - non significant; ***,*** - significant at P $\leq 0.05,0.01$ and 0.001 , respectively; different letters for the same element indicate significant differences according to Tukey's (HSD) multiple-range test $(\mathrm{P}=0.05)$.Legend: (CTRL100): control with $100 \%$ water and fertilization; (CTRL50): control with 50\% water and fertilization; (BAM100): B. amyloliquefaciens with 100\% water and fertilization; (BAM50): $B$. amyloliquefaciens with $50 \%$ water and fertilization.

Table 4 - Evaluation of B. amyloliquefaciens on the agronomic characters of Aeonium arboreum

\begin{tabular}{|c|c|c|c|c|c|c|}
\hline Groups & $\begin{array}{c}\text { Plant } \\
\text { height } \\
\text { (cm) }\end{array}$ & $\begin{array}{c}\text { Leaves } \\
\text { number } \\
\left(n^{\circ}\right)\end{array}$ & $\begin{array}{c}\text { Vegetative } \\
\text { weight } \\
\text { (g) }\end{array}$ & $\begin{array}{c}\text { Roots } \\
\text { weight } \\
\text { (g) }\end{array}$ & $\begin{array}{c}\text { Shoots } \\
\text { number } \\
\left(n^{\circ}\right)\end{array}$ & $\begin{array}{c}\text { F.oxysporum } \\
\text { plants } \\
\text { affected }\left(n^{\circ}\right)\end{array}$ \\
\hline CTRL100 & $14,91 \mathrm{~b}$ & $5,00 \mathrm{~b}$ & $42,66 \mathrm{~b}$ & $26,68 \mathrm{~b}$ & $1,61 \mathrm{~b}$ & $0,40 a b$ \\
\hline CTRL50 & $13,41 \mathrm{c}$ & $3,80 \mathrm{c}$ & $38,22 \mathrm{c}$ & $22,77 \mathrm{c}$ & $1,00 \mathrm{c}$ & $0,80 \mathrm{a}$ \\
\hline BAM100 & $18,05 \mathrm{a}$ & $6,40 \mathrm{a}$ & $43,48 \mathrm{a}$ & $30,58 \mathrm{a}$ & $2,80 \mathrm{a}$ & $0,00 \mathrm{~b}$ \\
\hline BAM50 & $14,97 \mathrm{~b}$ & $5,00 \mathrm{~b}$ & $42,25 \mathrm{~b}$ & $21,79 \mathrm{c}$ & $1,42 \mathrm{bc}$ & $0,20 \mathrm{ab}$ \\
\hline ANOVA & $* * *$ & $* * *$ & $* * *$ & $* * *$ & $* * *$ & ns \\
\hline
\end{tabular}

One-way ANOVA; n.s. - non significant; ${ }^{* * *, * * *}$ - significant at $\mathrm{P} \leq 0.05,0.01$ and 0.001 , respectively; different letters for the same element indicate significant differences according to Tukey's (HSD) multiple-range test $(\mathrm{P}=0.05)$.Legend: (CTRL100): control with $100 \%$ water and fertilization; (CTRL50): control with 50\% water and fertilization; (BAM100): B. amyloliquefaciens with 100\% water and fertilization; (BAM50): B. amyloliquefaciens with $50 \%$ water and fertilization.

Table 5 - Evaluation of B. amyloliquefaciens on the agronomic characters of Aeonium cv sunburst

\begin{tabular}{|c|c|c|c|c|c|c|}
\hline Groups & $\begin{array}{c}\text { Plant } \\
\text { height } \\
\text { (cm) }\end{array}$ & $\begin{array}{c}\text { Leaves } \\
\text { number } \\
\mathbf{( n}^{\circ} \mathbf{)}\end{array}$ & $\begin{array}{c}\text { Vegetative } \\
\text { weight } \\
\mathbf{( g )}\end{array}$ & $\begin{array}{c}\text { Root } \\
\text { weight } \\
\mathbf{( g )}\end{array}$ & $\begin{array}{c}\text { Shoots } \\
\text { number } \\
\left(\mathbf{n}^{\circ} \mathbf{)}\right.\end{array}$ & $\begin{array}{c}\text { F.oxysporum } \\
\text { plants } \\
\text { affected (n }\end{array}$ \\
\hline CTRL100 & $7,56 \mathrm{~b}$ & $5,20 \mathrm{~b}$ & $24,68 \mathrm{~b}$ & $13,35 \mathrm{~b}$ & $4,20 \mathrm{~b}$ & $1,21 \mathrm{a}$ \\
\hline CTRL50 & $6,43 \mathrm{c}$ & $4,10 \mathrm{c}$ & $22,97 \mathrm{c}$ & $12,91 \mathrm{~b}$ & $3,40 \mathrm{bc}$ & $0,85 \mathrm{a}$ \\
BAM100 & $8,61 \mathrm{a}$ & $6,40 \mathrm{a}$ & $26,84 \mathrm{a}$ & $15,94 \mathrm{a}$ & $5,60 \mathrm{a}$ & $0,21 \mathrm{~b}$ \\
BAM50 & $7,18 \mathrm{~b}$ & $5,20 \mathrm{~b}$ & $24,61 \mathrm{~b}$ & $13,29 \mathrm{~b}$ & $3,20 \mathrm{c}$ & $0,22 \mathrm{~b}$ \\
\hline ANOVA & $* * *$ & $* * *$ & $* * *$ & $* * *$ & $* * *$ & $* *$ \\
\hline
\end{tabular}

One-way ANOVA; n.s. - non significant; ${ }^{* * *, * * *}$ - significant at $\mathrm{P} \leq 0.05,0.01$ and 0.001 , respectively; different letters for the same element indicate significant differences according to Tukey's (HSD) multiple-range test $(\mathrm{P}=0.05)$. Legend: (CTRL100): control with $100 \%$ water and fertilization; (CTRL50): control with 50\% water and fertilization; (BAM100): B. amyloliquefaciens with 100\% water and fertilization; (BAM50): B. amyloliquefaciens with $50 \%$ water and fertilization. 

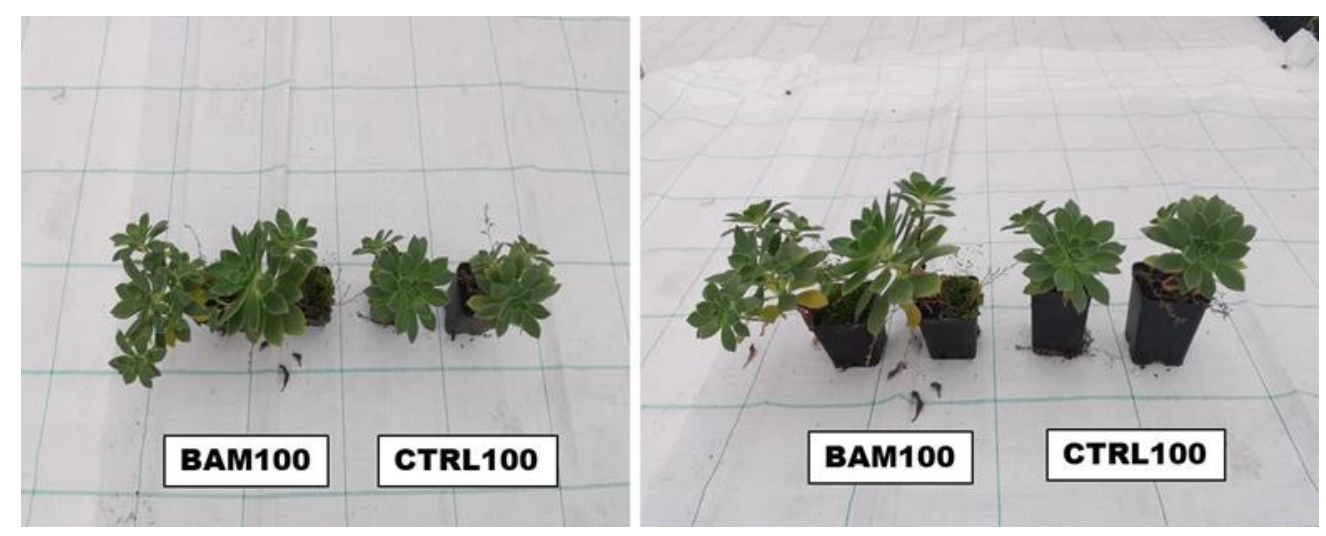

Figure 2 - Comparison between Bacillus amyloliquefaciens (BAM100) and control with 100\% water and fertilization (CTRL100) on growth of Aeonium haworthii

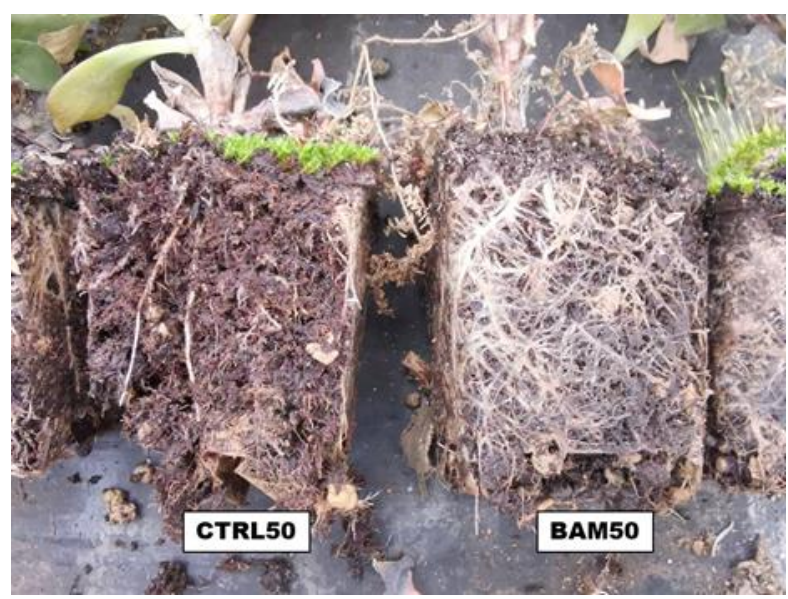

Figure 3 - Effect of Bacillus amyloliquefaciens with 50\% water and fertilization (BAM50) on growth roots of Aeonium haworthii
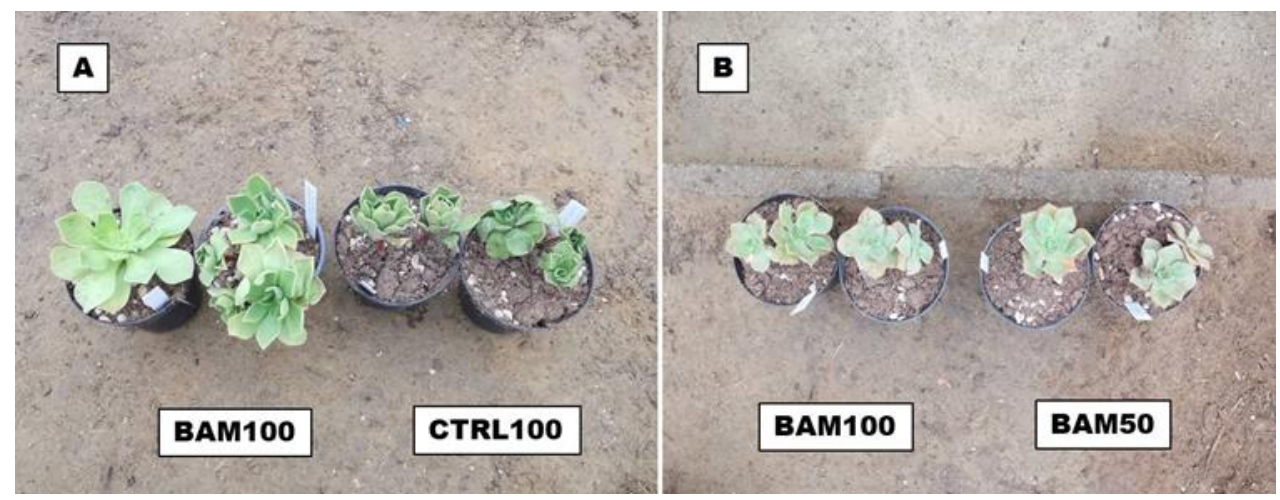

Figure 4 - Effect of Bacillus amyloliquefaciens with 100\% water and fertilization (BAM100) on vegetative growth of Aeonium goochiae (A); comparison of Bacillus amyloliquefaciens with $100 \%$ water and fertilization (BAM100) and Bacillus amyloliquefaciens with 50\% water and fertilization (BAM50) on Aeonium decorum (B) 


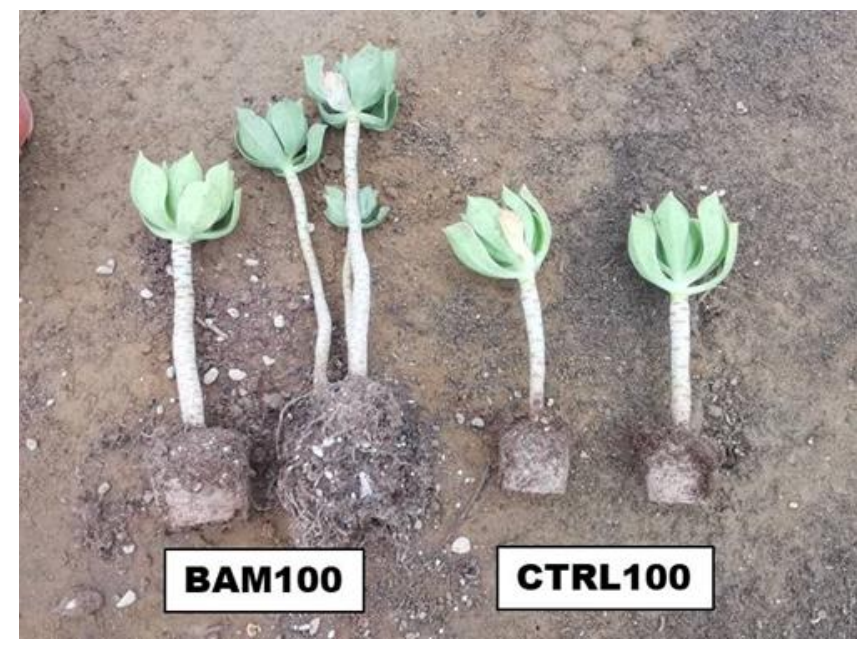

Figure 5 - Effect of Bacillus amyloliquefaciens with 100\% water and fertilization (BAM100) on vegetative and roots growth of Aeonium arboreum

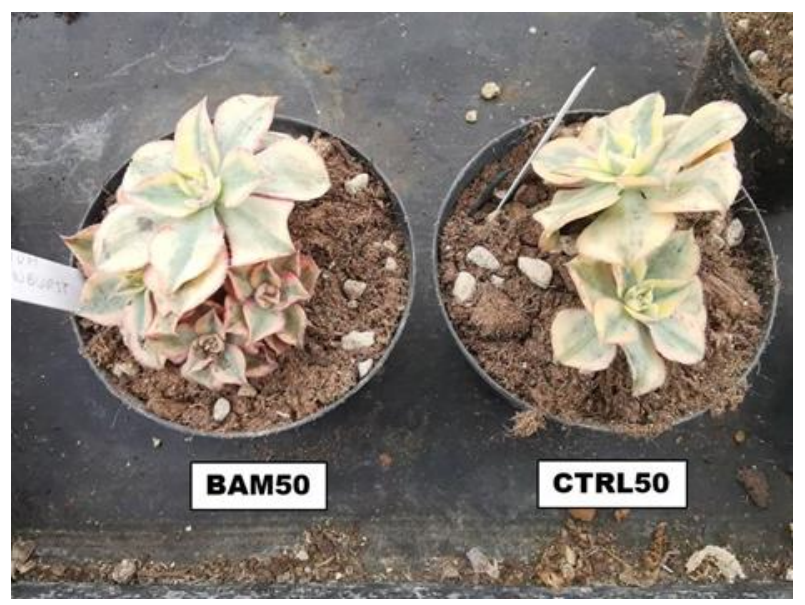

Figure 6 - Effect of Bacillus amyloliquefaciens with 50\% water and fertilization (BAM50) on vegetative and roots growth of Aeonium cv sunburts

\section{Discussion}

The presence of diverse microbial species in the soil ensures a high number of interactions between plant roots and bacteria and fungi in the soil. This can ensure an increase in crop production as a result of direct growth mechanisms mediated by the presence of PGPMs (Plant Growth Promoting Microorganisms), which can result in an increase in the production of growth regulators such as auxins, cytokinins and gibberellins, reduction in the production of stress hormones such as ethylene, increased uptake of water and nutrients. Indirect mechanisms such as the production of antibiotics, cell wall lytic enzymes or the induction of plant defense processes can inhibit the growth of phytopathogens [21].

Microorganisms play important roles in the biogeochemical cycles of organic and inorganic soil nutrients and ensure plant health and soil fertility. The application of microbial consortia during cultivation cycles can therefore create benefits during plant cultivation and promote environmental sustainability leading to increases in agricultural production [22,23].

In this study, theses treated with B. amyloliquefaciens showed improvement in all agronomic parameters analyzed on Aeonium plants and also increased protection against Fusarium oxysporum. This improvement was definitely driven by the abilities of $B$. amyloquefaciens to increase root development and consequently ensure greater water and nutrient uptake. This bacterium is also known to have the ability to stimulate plants on a hormonal and metabolic level. 
The rhizosphere is a complex habitat where the plant through the exudates of its roots can promote microbial growth and metabolism [24]. Soil microbiology greatly influences plant physiology and growth, but also protection from harmful pathogenic microorganisms. Beneficial microorganisms include plant growth-promoting rhizobacteria (PGPR), which generally live near roots or within specialized cells and are able to stimulate plant growth through a variety of mechanisms [20]. There are few studies involving the application of microorganisms and biostimulants in succulent and cactus cultivation that have demonstrated improvements in plant vegetative and root development, flower production, and especially with regard to increased protection from abiotic stresses and phytopathogens [25,26]. The main objective of this work is to enrich the literature with new studies concerning the application of microbial biostimulants on succulent plants, in this case Aeonium, providing more information to the farmer on new cultivation methods that are more environmentally friendly.

\section{Conclusion}

The trial on Aeonium plants showed how the application of B. amyloliquefaciens can significantly improve plant growth and defense. In particular, the use of microorganisms from the rhizosphere showed not only an increase in the agronomic characteristics of plants and roots, but also an increased defense against Fusarium oxysporum. Plants, thanks to the interaction with soil microorganisms, can reach higher nutrient and water resources, resulting in greater resistance to abiotic stresses and better quality in the cultivation cycle. In plants that have a fairly slow growth cycle, the use of B. amyloliquefaciens can certainly ensure an increase in the speed of development, with a reduction in water and nutrient inputs.

\section{Compliance with ethical standards}

\section{Acknowledgments}

The research is part of the project "MicroSuc: microorganisms for the growth and protection of cacti and succulent plants"

\section{Disclosure of conflict of interest}

The author declares no conflict of interest.

\section{References}

[1] Cecarini M. Piante grasse. Le succulente non cactacee. Guida pratica completa per coltivare, riconoscere, moltiplicare, difendere, curare le succulente non cactacee. 2011.

[2] Chapman P, Martin M. Cactus e altre succulente. Zanichelli. 1993.

[3] Eggli U. Illustrated handbook of succulent plants: Monocotyledons, Springer. 2001.

[4] Eggli U. Illustrated handbook of succulent plants: Crassulaceae, Springer. 2003.

[5] Hewitt T. Cactus e altre piante grasse, De Agostini. 1995.

[6] Jacobsen H. Handbook of Succulent plants, 3 volumes, Blandford Press. 1960.

[7] Chowdhury SP, Hartmann A, Gao XW. Biocontrol mechanism by root-associated Bacillus amyloliquefaciens FZB42-a review. Frontiers in Microbiology. 2015; 6: 780.

[8] Santoyo G, Orozco-Mosqueda MC, Govindappa M. Mechanisms of biocontrol and plant growth-promoting activity in soil bacterial species of Bacillus and Pseudomonas: A review. Biocontrol Science and Technology. 2012; 22: 855-872.

[9] Prisa D. Improving Quality of Crocus Sativus Through the Use of Bacillus Subtilis, International Journal of Scientific Research in Multidisciplinary Studies. 2020; 6(2): 9-15.

[10] Tahir HAS, Gu Q, Wu HJ, Niu YD. Bacillus volatiles adversely affect the physiology and ultra-structure of Ralstonia solanacearum and induce systemic resistance in tobacco against bacterial wilt. Scientific Reports. $2017 ; 7: 40481$.

[11] Gao ZF, Zhang BJ, Liu HP, Han JC. Identification of endophytic Bacillus velezensis ZSY-1 strain and antifungal activity of its volatile compounds against Alternaria solani and Botrytis cinerea. Biological Control. 2017; 105: 27-39. 
[12] Ryu CM, Farag MA, Hu CH, Reddy MS. Bacterial vol- atiles promote growth in Arabidopsis. Proceedings of the National Academy of Sciences of the United States of America. 2003; 100: 4927-4932.

[13] Prisa D. Effective microorganisms for germination and root growth in Kalanchoe daigremontiana. World Journal of Advanced Research and Reviews. 2019; 03(03): 047-053.

[14] Huang X, Zhang N, Yong X, Yang X. Biocontrol of Rhizoctonia solani damping-off disease in cucumber with Bacillus pumilus SQR-N43. Microbiological Research. 2012; 167: 135-143.

[15] Yuan J, Raza W, Shen QR, Huang QW. Antifungal activity of Bacillus amyloliquefaciens NJN-6 volatile compounds against Fusarium oxysporum f. sp. cubense. Applied and Environmental Microbiology. 2012; 78: 5942-5944.

[16] Wu Y, Zhou J, Li C, Ma Y. Antifungal and plant growth promotion activity of volatile organic compounds produced by Bacillus amyloliquefaciens. Microbiology Open. 2018.

[17] Arrebola E, Jacobs R, Korsten L. Iturin A is the principal inhibitor in the biocontrol activity of Bacillus amyloliquefaciens PPCB004 against postharvest fungal pathogens. Journal of Applied Microbiology. 2010; 108: 386-395.

[18] Jun Y, Lu Y, Ning L, Waseem R, Qirong S, Qiwei H. Plant-growth-promoting traits and antifungal potential of the Bacillus amyloliquefaciens YL-25, Biocontrol Science and Technology. 2015; 25(3): 276-290.

[19] Patten CL, Glick BR. Role of Pseudomonas putida indoleacetic acid in development of the host plant root system. Applied and Environmental Microbiology. 2002; 68: 3795-3801.

[20] Gray EJ, Smith DL. Intracellular and extracellular PGPR: Commonalities and distinctions in the plant-bacterium signaling processes. Soil Biology \& Biochemistry. 2005; 37: 395-412.

[21] Prisa D. Rhizobacteria and zeolites for overcoming saline stress in the cultivation of succulent plants. The International Journal of Engineering and Science (IJES). 2019; 8(5): Series I, Pages 38-41.

[22] Fernando WD, Nakkeeran S, Zhang Y. Biosynthesis of antibiotics by PGPR and its relation in biocontrol of plant diseases. In PGPR : Biocontrol and Biofertilization, Springer Netherlands. 2005; 67-109.

[23] Glick BR, Penrose DM, J. Li A model for the lowering of plant ethylene concentrations290 by plant growth promoting bacteria. Journal of Theoretical Biology. 1998; 190: 63-68.

[24] Kennedy AC. The rhizosphere and spermosphere. In : Principles and applications of soil microbiology, Upper Saddle River, New Jersy. 1999; 389-407.

[25] Prisa D. Effect of Azospirillum brasilense on garlic (Allium sativum L.) cultivation. World Journal of Advanced Research and Reviews. 2019; 02(03): 008-013.

[26] Prisa D. Effective Microorganisms And Chabazitic-Zeolites For The Improvement Quality Of Echinopsis Hybrids. Asian Academic Research Journal of Multidisciplinary. 2019; 6(2): 23-34. 